\title{
Foundations of the Evaluation of Export Performance by the Leaders of SME: Construction of a Measurement Scale
}

\author{
Ilhem Hammami and Mustapha Zghal
}

Faculty of Economics Sciences and Management of Tunis, Tunisia

Correspondence should be addressed to: Ilhem Hammami; elhemhammami@yahoo.fr

Received date: 30 December 2015; Accepted date: 12 April 2016; Published date: 26 July 2016

Academic Editor: Rym Kaddour Kaffel

Copyright (C) 2016. Ilhem Hammami and Mustapha Zghal. Distributed under Creative Commons CCBY 4.0

\begin{abstract}
Based on the emergent searches concerning the definition, the dimensions and the measurement of international marketing performance of the SME, the present article has for objective to propose a measurement scale of international marketing performance. The literature shows that authors use objective indicators or/and subjective ones. The lack of consensus between the researchers incited to us to make a qualitative study. And the second quantitative study led with 62 leaders of the SME allows building a measurement scale of international marketing performance by estimating the reliability of the initially identified dimensions and by verifying the validity and the reliability of four restraints.
\end{abstract}

Keywords: marketing performance, scale of measure, international, SME's.

\section{Introduction}

The present study allows arresting better the conceptualization of the measurement of export performance. A review of the emergent literature of the perception of the export performance is exposed, in a first part, and a construction of measurement scale of this concept based on an empirical study led with the leaders of the industrial SME, in a second part. The theoretical and practical contributions of the measurement scale proposed as well as the methodological limits and the ways of research are discussed at the end of the article.

\section{The literature Review}

\section{Definition of the export performance}

The export performance of SMEs is one of the subjects that focus on the attention of several researchers. It is defined by Cavusgil and Zou (1994) as « the degree of

Cite this Article as: Ilhem Hammami and Mustapha Zghal (2016), " Foundations of the Evaluation of Export Performance by the Leaders of SME: Construction of a Measurement Scale ", Journal of Marketing Research and Case Studies, Vol. 2016 (2016), Article ID 556493, DOI: 10.5171/2016.556493 
realization of the economic and strategic objectives of the company ».

The access to the international markets requires more important means, or to acquire a sufficient level of information on the market (consumer habits, adaptation of the product to a new environment, knowledge of the local competition), or to install a network of distribution and marketing and develop an adapted marketing strategy (Bricout J.L., 1991).

The international performance is defined by Baile S. and Djambou R. (2008) as "the capacity of a company to act on the international markets ". Also, certain authors as Luong M.H and al. (2010) suggest understanding the export performance as a comparison of results obtained abroad with the fixed objectives.

\section{Measurement scales and dimensions of export performance}

The literature review relative to international marketing reveals the use of a wide range of measurement tools for the performance such as the objective, subjective and composite measures of the export performance (Zou and Stan, 1998; Sapienza, Smith and Gannon, 1988; Gauzente, 2002; Lages and Jap, 2003). In the same context, Sousa (2004) stipulates that the export performance is essentially measured by three major dimensions such as the economic, strategic and subjective performance.

The research conducted by Katsikeas et al. (2000) allows identifying some fifty indicators of performance measurement. Indeed, these authors include these indicators in three categories: economic or objective indicators (percentage of export sales, market share in the export, the profit in the export, etc.), strategic (number of countries-export market, new exported products, etc.), and subjective (perception of the leader of its performances and successes in export, etc.).

Bouslama N. (2008) notices that, during 1980 s, there is an excess of use of economic indicators (objectives) compared with those strategic especially in the research realized during this period. This is explained by the fact that the previous research considered export as a means to realize economic objectives hence performance is measured in terms of sales or profits without a will to link it to the strategic objectives of the firm such as gain position on the overseas market (Cavusgil and Zou, 1994).

Also, we noticed that there is a difference between old and recent studies to know the number of dimensions used to measure the performance. Indeed, recent studies confirms the multidimensional nature of export performance by using multi items measures for example the studies led by Leonidou, Katsikeas and Samiee (2002); Ogunmokun Gabriel and Ng Simone (2004); Craig and O' Cass, (2004); Diamantopoulos (1999). Thus, these studies underline the limits bound to the use of one measurement indicator which characterizes the former searches (studies made between 1964 and 1996).

Abakouy (2006) stipulates that most research studies prefer to consider some indicators at the expense of the others, without caring about their complementary nature. According to this author, the use of multiple indicators has the advantage to explain the strength of every indicator and to minimize the impact of its defects. From this point of view, a multidimensional performance approach is the subject of a more and more solid consensus (Craig and Beamish, on 1989; Samiee and Walters, on 1990; Dominguez and Sequeira, on 1993; Bijmolt and Zwart on 1994; Cavusgil and Zou, on 1994; Zou and al. (1998); Zou and Stan, on 1998; Shoham, on 1998, p. 73).

As for Favre-bonte and giannelloni (2007), the definition and measurement of export performance always presents a rigorous lack because of the variety of approaches whose respective qualities and defects are still very widely discussed (Aaby and Slater, 1989; Cavusgil and Zou, 1994; Diamantopoulos and Schlegelmilch, 1994, Zou and al ., 1998). Indeed, studies carried out on the concept of the export performance have given contradictory results. This difference is explained by the operationalization of the export performance which is very different from one study to another which explains that there is a lack of consensus between the researchers. The latter develop objective 
and subjective measures and finally multidimensional measures or in a single indicator (Bouslama, 2008).

In the same context, Zou and Stan (1998), consistent with Madsen (1987) and Matthyssens and Pauwels (1996), distinguish three measures of export performance which are financial (objective), subjective and composite measures. Also, they distinguish the static measures of those who try to apprehend the changes of the export performance in time. Indeed, the scales which include a dimension "change" are seeking to capture the perception, by the manager, of the evolution in time of the performance of its company.

The objective indicators allow measuring objectively the profitability of the company, the level of export sales, etc. by using figures stemming from the history of the export.

Among the objective indicators presented by Sousa (2004) are: the number of country-export markets, the intensity of the export, the number of new countriesexport markets and the growth of the export turnover. The intensity of the export is measured by the share of the turnover achieved in export. The number of countries-export markets is a strategic performance indicator in the export. The stronger the presence of the company abroad is that is the number of countryexport markets is raised, the more experience it has acquired in the export and the higher the number of its foreign partners.

Finally, another measure of export performance is the number of new countries-export markets. Indeed, the companies that get new country-markets are developing more than those who do not have conquered new markets and/or that have lost markets.

Katsikeas, Piercy and Ioannidis (1996) consider that the objective measures of the export performance put two types of practical and methodological problems. Indeed, the reports of companies do not distinguish between the activities realized on the national market and those led on foreign markets. Then, it is difficult to isolate the export performances of the rest of the company's activities. In addition, it is not easy to compare the financial and economic data of a company with regard to another one because the mode of their elaboration and the techniques of calculation differ from a one company to another.

According to Favre-bonte and Giannelloni (2007), the objective measures also put two basic problems. The first one is associated to the availability of information. Indeed, the variability of the accounting methods of companies casts a doubt on what is really measured in terms of international activity. Thus, among the major problems encountered by the empirical research concerning SME is to obtain data on the export performance and it is because, on one hand, small companies do not accept to disclose financial information concerning their export activities (Nakos, Brouthers and Brouthers, 1998). And, on the other hand, a lot of them do not have appropriate documents on the export.

The second problem is of theoretical order. Indeed, the export decision-makers are guided by their subjective perceptions of the performance of the company to the international, more than by objective and absolute ratios of performance.

The subjective performance of SME in the export allows measuring the satisfaction of the leader with regard to the realization of the objectives in the export by his company. The appreciation of a company by its leader constitutes so important information as the numerical results.

Thus, Leonidou, Katsikeas and Samiee (2002) notice that the subjective measures are linked to the perception of the exporting activity and sources of several biases for example the managers who consider that the export is a risky and expensive activity will announce low export performances even if it is not real. By contrast, an increasing number of empirical research studies indicate a good level of reliability and validity of the subjective measures of performance 
(Cowine and Slevin, 1988; Venkatraman and Ramanujam, 1987; Dess and Robinson, 1984). Thus, according to certain authors, the subjective measures of performance are better than the objective measures because the accounting information is not always available and even less reliable because it can be manipulated for diverse reasons (Baile S. and Djambou R., 2008).

However, we have found, in studies conducted in 1990s and 2000, that there is a strong trend to the use of subjective measures much more than the objective ones (Leonidou, Katsikeas and Samiee, on 2002; Bijmolt and Zwart, on 1994; Zou and Stan, on 1998; Whited, Griffith, Ryans and Jr, on 1998). But, the success is relative; it varies according to the perception of the manager according to Louter, Ouverkerk and Bekker (1991). Indeed, because of the differences related to the anticipations and to the expectations of the leaders, given realizations can be considered as a high performance by a manager and as insufficient or low by another.

Among the subjective measures, we find for example, the perception of success in the export by the manager, the perception of growth or profit as well as the satisfaction of the manager towards the export performance.

There are in the literature three subjective and dynamic scales which measure the perceived performance and integrate the perception, by the respondent, of the evolution of export performance which are the composite scale of Shoham (1998), the scale EXPERF and STEP Scale proposed by Lages and Lages (2004). The composite scale of Shoham (1998) integrates an approach of "the intensity" of the export activity which is measured by the ratio export sales on total sales of the company (Beamish and Munro, 1986; Dominguez and Sequeira, 1993); the satisfaction expressed towards export sales and perceived change in the performance over a period of five years. The scale of measure EXPERF is composite and threedimensional and integrated the concept of satisfaction (Zou and al., 1998). Finally, and based on the work of Madsen (1998), Lages and Lages (2004) propose the STEP Scale which is designed to measure the perception of improvement of the performance export in the short-term. This scale is purely subjective and dynamic and articulates around the dimensions "Satisfaction towards the improvement of performance in the short-term", "improvement of the intensity of export activity on the short term" and "expected improvement of the performance in the short term".

The literature review relative to international marketing reveals on one hand, the tendency to the combination of quantitative and qualitative approaches of measure of the perception and, on the other hand, the use in the recent studies of several indicators of measure (studies multicriteria) (Moini, 1997; Leonidou, Katsikeas and Samiee, 2002).

The literature review in international marketing allowed us to identify a wide variety of indicators of measurement of export performance (a list of 27 items), which reflects the lack of consensus between the researchers. The table below illustrates this variety. 
Table 1: The indicators of measurement of export performance

\begin{tabular}{|c|c|}
\hline Items & References \\
\hline $\begin{array}{l}\text { The percentage of export sales with regard to the total sales } \\
\text { (intensity in the export) }\end{array}$ & \multirow{27}{*}{$\begin{array}{l}\text { Roth (1997), Samee \& Roth } \\
\text { (1998), Katsikaes and al (2000), } \\
\text { Albaum \& Tse (2001), Julien \& } \\
\text { Ramangahaly (2002), Katsikaes } \\
\text { and al (2002), Lages \& Lages } \\
\text { (2002), Ramangahaly (2003), } \\
\text { Carneiro and al (2007), Sousa } \\
\text { and al (2008), Carneiro and al } \\
\text { (2009), Navarro (2010) }\end{array}$} \\
\hline The growth of export sales & \\
\hline The sales volume in the export & \\
\hline $\begin{array}{l}\text { The growth of the percentage of export sales with regard to } \\
\text { the total sales }\end{array}$ & \\
\hline The profitability in the export & \\
\hline The growth of the profitability in the export & \\
\hline The market share in the export & \\
\hline $\begin{array}{l}\text { The growth of the export market share since the beginning } \\
\text { of the export activities of your company }\end{array}$ & \\
\hline The number of export markets & \\
\hline The penetration of export markets & \\
\hline The realization of the objectives in the export & \\
\hline Satisfactions of foreign customers & \\
\hline Retention of the foreign customers & \\
\hline Acquisition of new foreign customers & \\
\hline Quality of the services & \\
\hline $\begin{array}{l}\text { Quality of the relation between your company and the } \\
\text { foreign distributor }\end{array}$ & \\
\hline The reputation of your company & \\
\hline Loyalty of the foreign distributor towards your company & \\
\hline $\begin{array}{l}\text { General satisfaction towards the offer of products or } \\
\text { services exported by your company }\end{array}$ & \\
\hline Count new exported products & \\
\hline $\begin{array}{l}\text { The satisfaction of the executive management of your } \\
\text { company towards the growth of sales abroad }\end{array}$ & \\
\hline $\begin{array}{l}\text { The satisfaction of the executive management towards the } \\
\text { fame and the image of your company }\end{array}$ & \\
\hline $\begin{array}{l}\text { The satisfaction of the executive management towards the } \\
\text { profitability of sales abroad }\end{array}$ & \\
\hline $\begin{array}{l}\text { The satisfaction of the executive management towards the } \\
\text { market share associated with the export activity }\end{array}$ & \\
\hline $\begin{array}{l}\text { The satisfaction of the executive management towards the } \\
\text { expansion of the company to the international }\end{array}$ & \\
\hline $\begin{array}{l}\text { The satisfaction of the executive management of your } \\
\text { company towards the penetration to the overseas markets }\end{array}$ & \\
\hline $\begin{array}{l}\text { The satisfaction of the executive management of your } \\
\text { company towards the realization of the objectives in the } \\
\text { export }\end{array}$ & \\
\hline
\end{tabular}

Source: Created by the author(s)

Ilhem Hammami and Mustapha Zghal (2016), Journal of Marketing Research and Case Studies, DOI: $10.5171 / 2016.556493$ 


\section{Construction of a measurement scale}

In this second part of the research, we present the methodology and the steps of construction of a measurement scale of export performance. Indeed and as in most of the studies of construction of scale, the approach of Churchill has been applied with its two main steps: the elaboration of a qualitative study in order to generate a sample of items and the purification of the latter by the exploratory factorial analysis.

\section{Constitution of the sample of items}

In a rigorous objective, this step leaned on the principle of diversification of the sources of data to constitute the sample of items, on one hand, and confirm the dimensions previously identified in the literature, on the other hand: it is, in the first place, semi-structured interviews and, secondly, the advice of experts.

To constitute the sample, we addressed the basis of the lists of the exporting companies established by the Center of Promotion of Exports (CEPEX). These companies have been recruited on the basis of the criterion of diversity in terms of size (between 10 and 250 employees), type of exported products and the export rate (see table). Thus, our research concerned the leaders of the Tunisian industrial SME and which are partially exporting.

The objective of the semi-structured interviews is to determine the foundations of the evaluation of the export performance by the leaders of the industrial exporting
SME to become attached directly to their speech. To do this, we have developed a guide of interview which is articulated around the axes reflecting the problematic of the study, by respecting the rules required (Giannelloni and Vernette, 2001). Overall, the main theme was treated which comes from the literature and a discussion with the leaders of companies. We have taken care to respect the neutrality and objectivity of the speeches of the leaders. These have since been the subject of a thematic content analysis after having been fully and accurately recorded and saved.

Thus, we leaned on the rule of "semantic saturation" to optimize the number of the interviewees' which was not statistically representative but rather timely to reflect the diversity of the population studied (Evrard and al. 1993, Romelaer, 2002).

Twelve individual interviews of an approximate duration of forty-five minutes were organized with the leaders of the industrial exporting SME. All the retranscribed speeches were analyzed according to the device thematic content analysis (Bardin, 2001). Finally, we had resorts to the opinions of three experts having an important experience in the field of the export in order to submit and study an initial sample of 27 items.

The content analysis relative to the qualitative phase allowed generating 11 items supposed of the export performance and which will be submitted to the pre-test. We present the synthesis of these results in the following table (table 2): 
Table 2: Some detailed elements of the thematic content analysis: the export performance

\begin{tabular}{|c|c|c|}
\hline Unit of identified analysis & Examples of expressed verbatim & $\begin{array}{l}\text { Index of } \\
\text { appearance }\end{array}$ \\
\hline intensity in the export & $\begin{array}{l}\text { "... Successful being, it is to realize a high } \\
\text { percentage of export sales with regard to the } \\
\text { total sales of the company». }\end{array}$ & $7 / 11$ \\
\hline The growth of export sales & $\begin{array}{l}\text { "The performance of a company in the } \\
\text { export is translated by the growth of sales on } \\
\text { the international market» }\end{array}$ & $9 / 11$ \\
\hline $\begin{array}{l}\text { The perceived profitability from the } \\
\text { export activity with regard to the } \\
\text { activity on the local market }\end{array}$ & $\begin{array}{l}\text { "The company is considered successful when } \\
\text { the activity of export is more profitable than } \\
\text { the activity on the local market" }\end{array}$ & $6 / 11$ \\
\hline $\begin{array}{l}\text { The growth of the profitability in the } \\
\text { export }\end{array}$ & $\begin{array}{l}\text { "The export performance is measured by the } \\
\text { growth of the profitability abroad" }\end{array}$ & $8 / 11$ \\
\hline The number of export markets & $\begin{array}{l}\text { "The performance is reflected by the number } \\
\text { of markets served to the export ... ». }\end{array}$ & $5 / 11$ \\
\hline Acquisition of new foreign customers & $\begin{array}{l}\text { "The performance is measured by the } \\
\text { number of new acquired foreign customers » }\end{array}$ & $6 / 11$ \\
\hline The reputation of your company & $\begin{array}{l}\text { "The measurement of export performance is } \\
\text { a function of the fame and the reputation of } \\
\text { our company ... » }\end{array}$ & $7 / 11$ \\
\hline $\begin{array}{l}\text { The satisfaction of the executive } \\
\text { management of your company } \\
\text { towards the growth of sales abroad }\end{array}$ & $\begin{array}{l}\text { "A company is considered as successful in } \\
\text { the export when the leader(manager) is } \\
\text { satisfied by the level of sales realized abroad } \\
\text { which must move towards the growth» }\end{array}$ & $8 / 11$ \\
\hline $\begin{array}{l}\text { The satisfaction of the executive } \\
\text { management towards the fame and } \\
\text { the image of company }\end{array}$ & $\begin{array}{l}\text { "... Successful being, it is to be satisfied by } \\
\text { the fame and the image of my company } \\
\text { abroad» }\end{array}$ & $4 / 11$ \\
\hline $\begin{array}{l}\text { The satisfaction of the executive } \\
\text { management towards the profitability } \\
\text { of sales abroad }\end{array}$ & $\begin{array}{l}\text { "To consider my company as successful in } \\
\text { the export, I must be satisfied by the profit } \\
\text { realized abroad» }\end{array}$ & $9 / 11$ \\
\hline $\begin{array}{l}\text { The satisfaction of the executive } \\
\text { management of your company } \\
\text { towards the realization of the } \\
\text { objectives in export }\end{array}$ & $\begin{array}{l}\text { "Successful being it is to be satisfied by the } \\
\text { results realized abroad and by the } \\
\text { realization of the international objectives" }\end{array}$ & $10 / 11$ \\
\hline
\end{tabular}

Source: Created by the author(s)

\section{Purification step of the scale}

It is a question for the purification phase of a pre-test stage of 11 reserved items. Indeed, the pre-test was made on a convenience sample composed of leaders of diverse Tunisian exporting companies. The composition of the sample was heterogeneous in terms of the business sector and the seniority in the export (Appendix 2).
According to Akrout (2010), the minimal size of the sample recommended for a pretest is 60 interviewees. Thus, by referring to this author, our sample is composed of 62 leaders of the Tunisian exporters SME.

We have administered all questionnaires in paper version. In addition to the items proposed in the questionnaire, we have integrated an open question on the suggestions of the respondents concerning 
the foundations of the evaluation of the export performance of their companies. The analysis of contents, that has followed, has enabled us to reformulate the items which were badly formulated during the pre-test.

Afterward, we have applied an exploratory factor analysis of ACP type (principal component analysis) by using the software SPSS 20 followed by a confirmatory analysis relating to the validation of the factorial structure under the software AMOS 18.

Thus, following the pre-test, we found four factors mono item where the saturation item/factor always exceeds the value 0,6. The raised factor structure allows explaining $77,3 \%$ of the total variance.

\section{Results}

Starting from eleven items which are mainly generated from the results of the content analysis of the qualitative study, the process of factor analysis allowed reaching four items: the final items are relatively corresponding with the contributions of the main emergent studies in literature (previously cited). Often, each of these items - intensity in the export, growth of export sales, profitability received of the export activity compared to the activity on the local market and the satisfaction of the executive management towards the profitability of sales abroad was separately evoked in one of the main measurement scales presented previously. The results of construction of our scale (see table 3) allow better apprehending and understanding of the foundations of judgment and evaluation of the leader towards the performance of his company in the

export.

Table 3: Results of purification steps of the measurement scales

\begin{tabular}{|l|l|}
\hline Initial scale after qualitative phase & Scale after pre-test \\
\hline items: 11 & items: 4 \\
\hline Intensity in the export & Intensity in the export \\
\hline The growth of export sales & The growth of export sales \\
\hline $\begin{array}{l}\text { The perceived profitability from the } \\
\text { export activity with regard to the } \\
\text { activity on the local market }\end{array}$ & $\begin{array}{l}\text { The perceived profitability from the export } \\
\text { activity with regard to the activity on the } \\
\text { local market }\end{array}$ \\
\hline $\begin{array}{l}\text { The satisfaction of the executive } \\
\text { management towards the profitability } \\
\text { of sales abroad }\end{array}$ & $\begin{array}{l}\text { The satisfaction of the executive } \\
\text { sales abroad }\end{array}$ \\
\hline $\begin{array}{l}\text { The growth of the profitability in the } \\
\text { export }\end{array}$ & \\
\hline The number of export markets & \\
\hline $\begin{array}{l}\text { Acquisition of new foreign customers } \\
\text { The reputation of your company }\end{array}$ & \\
\hline $\begin{array}{l}\text { The satisfaction of the executive } \\
\text { towards the growth of sales abroad }\end{array}$ \\
\hline
\end{tabular}

Ilhem Hammami and Mustapha Zghal (2016), Journal of Marketing Research and Case Studies, 


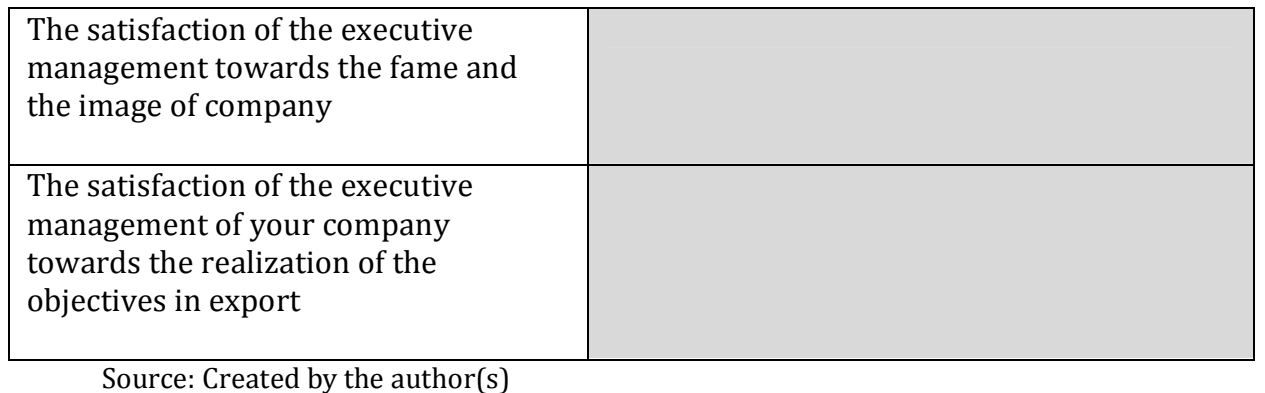

The constitutive dimensions of this measurement scale of export performance allow consolidating the postulate of certain authors in international marketing (Katsikeas and al., 2000; Sousa, 2004) who argue that export performance is characterized by its multidimensional nature. Thus, the use of multiple indicators presents the advantage to explain the strength of each indicator and to minimize the impact of its defects (Abakouy, 2006).

We present in table 4 the results of the factorial structure of eleven items after the exploratory factorial analysis

Table 4: factorial structure of the export performance (Pre-test)

\begin{tabular}{|l|c|c|}
\hline \multicolumn{1}{|c|}{ items } & F1 & Community \\
\hline Average intensity in the export & 0,716 & 0,651 \\
\hline Stability of the export rate & 0,894 & 0,791 \\
\hline $\begin{array}{l}\text { Perceived evaluation of the } \\
\text { profitability of export. }\end{array}$ & 0,880 & 0,778 \\
\hline $\begin{array}{l}\text { Evaluation of the influence } \\
\text { exercised by the export on the } \\
\text { global profitability of the } \\
\text { company }\end{array}$ & 0,772 & 0,698 \\
\hline \multicolumn{1}{|c|}{ Explained variance } & $\mathbf{7 7 , 3 \%}$ \\
\hline \multicolumn{1}{|c|}{ Index KM0 } & $\mathbf{0 , 8 3 6}$ \\
\hline
\end{tabular}

Source: Created by the author(s)

The value of the index KMO is 0,827 which implies that the data can be factorized. Furthermore, the Varimax rotation leads to a factorial structure with a single factor. Note that the set of items exceeds a community of 0,5 and that the coefficients of internal coherence are relatively satisfactory.

Remember that in the context of this study, it is a question of explaining the export performance by the constitutive dimensions of this performance. To do this, we proceeded to a linear regression to test the impact of dimensions identified on export performance. Similarly, the results of the study of the convergent validity of measurement scale are satisfactory concerning the global adjustment and the correlations between variables (table 5 and 6). Remember that the correlation is considered significant beyond the value 0,01 . 
Table 5: Correlation between the factors of the export performance

\begin{tabular}{|l|c|}
\hline \multicolumn{1}{|c|}{ Items } & $\begin{array}{c}\text { Export } \\
\text { performance }\end{array}$ \\
\hline Average intensity in the export & 0,53 \\
\hline Stability of the export rate & 0,51 \\
\hline $\begin{array}{l}\text { Perceived evaluation of the } \\
\text { profitability of export. }\end{array}$ & 0,47 \\
\hline $\begin{array}{l}\text { Evaluation of the influence } \\
\text { exercised by the export on the } \\
\text { global profitability of the } \\
\text { company }\end{array}$ & 0,43 \\
\hline
\end{tabular}

Source: Created by the author(s)

Table 6: Study of the linear regression*

\begin{tabular}{|l|c|c|c|c|}
\hline \multicolumn{1}{|c|}{ items } & Link & $\begin{array}{c}\text { Coef. } \\
\text { Standard } \\
\text { Beta }\end{array}$ & t & Signification \\
\hline $\begin{array}{l}\text { Average intensity in the } \\
\text { export }\end{array}$ & + & 0,169 & 1,984 & 0,05 \\
\hline Stability of the export rate & + & 0,327 & 4,21 & 0 \\
\hline $\begin{array}{l}\text { Perceived evaluation of the } \\
\text { profitability of export. }\end{array}$ & + & 0,198 & 2,468 & 0,015 \\
\hline $\begin{array}{l}\text { Evaluation of the influence } \\
\text { exercised by the export on the } \\
\text { global profitability of the } \\
\text { company }\end{array}$ & + & 0,174 & 2,238 & 0,027 \\
\hline
\end{tabular}

* Dependent Variable: export Performance*

Source: Created by the author(s)

\section{Discussion, limits and ways of Research}

We have presented and discussed in this article the state of the art in terms of indicators of international marketing measurement of performance. The literature specified, on one hand, the importance of the use of multidimensional measures containing indicators that are only objective or subjective or both, and on the other hand, the preponderance of subjective indicators in measurement of the performance.

Then, and at the lack of consensus among the researchers, we have developed a qualitative study in the form of semistructured interviews with the leaders in order to illustrate (in the context of emerging countries, such as Tunisia) the problem of operationalization of the international marketing performance.

Afterward, we have led to a measurement scale which allows us to dread and better understand the foundations of the judgment of the manager concerning the export performance of his company. The evaluation of this last is mainly based on the subjective aspect (through the perceived evaluation of the profitability of export, the evaluation of the influence exercised by the export on the global profitability of company and the stability of the export rate), next to the objective aspect (through the average intensity in the export). 
This measurement scale is characterized by its multidimensional nature of the performance which uses multi- items measures and this confirms the results of the studies led by Leonidou, Katsikeas and Samiee (2002); Ogunmokun Gabriel and Ng Simone (2004); Craig and Cass, (2004); Diamantopoulos (1999). Therefore, our research reveals, on one hand, the importance of subjective indicators, and on the other hand, the necessity of resorting to several indicators.

The main managerial implications of this study were manifested at the level of the measurement of export performance of the SME. In effect, if the present scale is capable to measure the perception of the export performance, it could constitute a set of valid criteria for evaluating the export performance of an SME.

Furthermore, the more or less important contributions of the constitutive dimensions of the export performance can constitute a help tool in comparison of SME competing on an international scale.

Certain methodological limits make that the present research remains exploratory. Actually, the 62 respondents during the pre-test seem to constitute a sample of people limited in number for the data collection phase. Thus, we recommend realizing a longitudinal study on a more important sample to verify the solidity of our conclusions in the time and the possibility of generalization of the present results. We also recommend targeting a sample of SME belonging to the same sector in order to verify the homogeneity of the

results.

\section{Appendix}

\section{Appendix 1: Description of samples for the qualitative study}

\begin{tabular}{|c|c|c|c|}
\hline Company & $\begin{array}{c}\text { Size (number of } \\
\text { permanent } \\
\text { employees) }\end{array}$ & Business sector & $\begin{array}{c}\text { Export Rate (during the 3 } \\
\text { years) }\end{array}$ \\
\hline 1 & 40 & textile & More than $60 \%$ \\
\hline 2 & 220 & Agri-food & Less than $30 \%$ \\
\hline 3 & 60 & Plastic & More than $60 \%$ \\
\hline 4 & 80 & Pharmaceutical & Between $30 \%$ and $60 \%$ \\
\hline 5 & 24 & Plastic & Between $30 \%$ and $60 \%$ \\
\hline 6 & 240 & Pharmaceutical & Less than $30 \%$ \\
\hline 7 & 33 & Agri-food & Less than $30 \%$ \\
\hline 8 & 250 & textile & Between $30 \%$ and $60 \%$ \\
\hline 9 & 75 & Plastic & More than $60 \%$ \\
\hline 10 & 140 & Pharmaceutical & Between $30 \%$ and $60 \%$ \\
\hline 11 & 50 & Agri-food & More than $60 \%$ \\
\hline 12 & 170 & \multicolumn{2}{c}{} \\
\hline
\end{tabular}

Source: Created by the author(s) 
Appendix 2: Description of samples for the pre-test

\begin{tabular}{|c|c|c|c|c|c|c|c|c|c|}
\hline & \multirow{2}{*}{$\begin{array}{l}\text { Tested } \\
\text { items }\end{array}$} & \multirow{2}{*}{$\begin{array}{l}\text { Validated } \\
\text { questionna } \\
\text { ires }\end{array}$} & \multirow{2}{*}{$\begin{array}{l}\text { Cancelled } \\
\text { questionn } \\
\text { aires }\end{array}$} & \multicolumn{3}{|c|}{ Business sector (\%) } & \multicolumn{3}{|c|}{ Export experience (\%) } \\
\hline & & & & Text & Agri & Plasti & $\begin{array}{c}<5 y e a \\
\text { rs }\end{array}$ & $\begin{array}{c}\text { Between } 5 \\
\text { and } \\
\text { 10years }\end{array}$ & $\begin{array}{c}\text { >10yea } \\
\text { rs }\end{array}$ \\
\hline $\begin{array}{l}\text { Pre- } \\
\text { test }\end{array}$ & 11 & 62 & 5 & 50 & 25 & 25 & 17 & 33 & 50 \\
\hline
\end{tabular}

Source: Created by the author(s)

\section{References}

1. Abakouy M. (2006) «Performances à l'international de la PME marocaine », 8ème congrès international Francophone en entrepreneuriat et $P M E, 25,26,27$ octobre 2006, Suisse.

2. Akrout F. (2010) «Les Méthodes des Equations Structurelles », 1ère édition 2010.

3. Baile S. et DJAMBOU R. (2008) "Gouvernance TI et Performance à l'International des PME Gabonaises : Une modèle d'analyse du Succès des TIC basé sur les Ressources», 9ème Congrès CIFEPME, Univ. Catholique de Louvail, 2931 Octobre 2008.

4. Bardin L. (2001) "l'analyse de contenu", édition PUF, Paris, 2001, 200 pages

5. Bijmolt T.H.A. and Zwart P.S. (1994) « The Impact of Internal Factors on the Export Success of Dutch Small and Medium-Sized Firms ", Journal of Small Business Management, (april), pp.69-83.

6. Bouslama N. (2008) «Quels indicateurs de mesure de la performance marketing à l'export? ", Journal of Global Management Research 2008.

7. Bricout J.L. (1991) «Exporter : une question de taille », Economie et statistique, $\mathrm{N}^{\circ} 244$, Juin 1991.

8. Cavusgil S.T. and Zou S. (1994) «Marketing Strategy-Performance Relationship: An Investigation of the empirical link in export market ventures », Journal of Marketing, vol 58.

9. Craig J.C and O'cass A. (2004) «The antecedents of export marketing performance: An Australian perspective », Journal of Asia pacific marketing, vol 3, $\mathrm{N}^{\circ} 2$, pp.99-113.

10. Craig R. and P.W. Beamish (1989) «A Comparison of the Characteristics of Canadian and U.K. Exporters by Firm Size », Journal of Global Marketing, 2: 4, pp.49-64.

11.Diamantopoulos A. (1999) « View point-export performance measurement: reflective versus formative indicator ", International Marketing Review, vol 16, $\mathrm{N}^{\circ} 6$.

12.Dominguez L.V. and C.G. Sequeira (1993) « Determinants of LDC Exporters Performance: a Cross-national study », Journal of International Business Studies, 24: 1, pp.19-40.

13.Evrard Y., Pras B. et Roux E. (1993) "Market, études et recherches en marketing, fondements et méthodes", édition Nathan, Paris, 1993, 629 pages.

14.Favre-Bonte V. et Giannelloni J. L. (2007) «L'influence des caractéristiques de personnalité du dirigeant de PME sur la performance à l'export», XVIème Conférence Internationale de Management Stratégique, Montréal, 6-9 Juin 2007. 
15.Giannelloni J.L. et Vernette E. (2001) « Etudes de marché », Paris, Vuibert.

16.Katsikeas C.S., Leonidou L.C. and Morgan N.A. (2000) « Firm-level export performance assessment: Review, Evaluation and Development » Journal of the Academy of Marketing Science, vol 28, $\mathrm{n}^{\circ} 4$.

17.Katsikeas C.S., Piercy N.F. and Ioannidis C. (1996) «Determinants of Export Performance in a European Context», European Journal of Marketing, vol. 30, n6, pp. 6-35.

18.Lages L.F. and Lages C.R. (2004) « The STEP Scale: A measure of short-Term Export performance improvement ", Journal of International Marketing, vol 12, $\mathrm{n}^{\circ} 1$.

19.Lages L.F. and Jap S.D. (2003) « The Relationship among Past Export Performance, Marketing Mix Adaptation, and Current Export Performance Improvement in Global Marketing Relationships ", Papier présenté au MSI / International Journal of Research in Marketing: "Research Competition on Global Marketing", Noordwijk, the Netherland, 9-10 Juin.

20.Leonidou L.C., Katsikeas K. and Samiee S. (2002) « Marketing Strategy determinants of export performance: a meta-analysis » Journal of Business Research, vol 55, pp.51-6.

21.Luong M.H, Leo P.Y. et Philippe J. (2010) «Les antécédents de la performance à l'exportation des PME: un modèle hiérarchisant les déterminants, application au Vietnam », 10 ème Congrès International Francophone en Entrepreneuriat et PME, Association Internationale de Recherche en Entrepreneuriat et PME.

22.Madsen T.K. (1987) «Empirical export performance studies: a review of conceptualizations and findings ", in Cavusgil S.T. and Axinn C. (Eds), Advances in International Marketing, JAI Press, Greenwich, CT, 2, pp.177-198.
23.Madsen T.K (1989) «Successful export marketing management: some empirical evidence», International Marketing Review, vol $6, n^{\circ} 4$.

24.Matthyssens P. and Pauwels P. (1996) « Assessing export performance measurement», in Cavusgil S.T. and Axinn C. (Eds), Advances in International Marketing, JAI Press, Greenwich, CT, 8, pp.85-114.

25.Moini A.H. (1997) «Barriers Inhibiting Export Performance of Small and Medium Sized Manufacturing Firms », Journal of Global Marketing, vol. 10, n 4 , pp. 67-93.

26. Nakoes G., Brouthers K. D., and Lance E. (1998) « Impact of firm and managerial characteristics On small and medium sized greek firms' export performance ", Journal of global marketing, vol $11, \mathrm{n}^{\circ} 4$, pp.23-47.

27.Ogunmokun G. and Ng S. (2004) "Factors influencing export performance in international marketing: A study of Australian firms" International Journal of Management, vol 21, $\mathrm{N}^{\circ} 2$, Juin 2004, pp:172-185

28. Romelaer P. (2002), Notes sur l'entretien semi-directif centré, CEFAG, Séminaire «Méthodes qualitatives de Recherche en gestion », La Londe Les Maures.

29.Samiee S. and Walters P.G. (1990) « Influence of Firm Size on Export Planning and Performance », Journal of Business Research, vol 20, n³, pp.235-248.

30.Shoham A. (1998) « Export Performance: A Conceptualization and Empirical Assessment», Journal of International Marketing, 6: 3, pp.59-81.

31.Sousa C.M.P (2004) « Export Performance Measurement: An Evaluation of the Empirical Research in the Literature ", Academy of Marketing Science Review, $\mathrm{n}^{\circ} 09,2004$.

32.Zou S. and Stan S. (1998) « The determinants of export performance: A review of the empirical literature between 
1987 and 1997 », International Marketing Review, vol 15, n5, pp. 333-356.

33.Zou S., Taylor C.R. and Osland G.E. (1998) « The EXPERF scale: A CrossNational Generalized Export Performance
Measure», Journal of International Marketing, vol 6, $\mathrm{n}^{\circ} 3$, pp.37-58.

34.Whited S, Griffith D.A. and Rayans J.K. (1998) « Measuring export Performance in service industries », International Marketing Review, vol 15, $\mathrm{n}^{\circ} 3$, London, pp. 188- 